\title{
An Applied Econometricians' View of Empirical Corporate Governance Studies
}

\author{
Axel Börsch-Supan* and Jens Köke**
}

April 2000

\begin{abstract}
The economic analysis of corporate governance is en vogue. In addition to a host of theoretical papers, an increasing number of empirical studies analyze how ownership structure, capital structure, the structure of the board and the market for corporate control influence firm performance.

This is not an easy task, and indeed, for reasons explained in this survey, empirical studies on corporate governance have more than the usual share of econometric problems. Aim of this paper is a critical survey of the recent empirical literature on corporate governance - in order to show which methodological lessons can be learned for future empirical research in the field of corporate governance, paying particular attention to German institutions and data availability.
\end{abstract}

Keywords: Corporate governance

JEL Classification: G30

\footnotetext{
* University of Mannheim, Germany; NBER, Cambridge, Mass., USA; and ZEW, Mannheim, Germany

** Centre for European Economic Research (ZEW), Mannheim, Germany

Address for correspondence:

Jens Köke

P.O. Box 103443

68034 Mannheim, Germany

Phone: 0049-621-1235-190

E-mail: koeke@zew.de
} 


\section{Non-Technical Summary}

The economic analysis of corporate governance is en vogue. In addition to a host of theoretical papers, an increasing number of empirical studies analyze how ownership structure, capital structure, the structure of the board and the market for corporate control influence firm performance.

Aim of this paper is a critical survey of the recent empirical literature on corporate governance with an emphasis on the methodological lessons that can be learned for future empirical research in the field of corporate governance. We structure the paper by four categories of econometric problems that have to be solved in order to infer causal effects of corporate governance: reverse causality, missing variables, sample selectivity, and measurement error in variables. In each section, we briefly describe the econometric problem pretty much in a textbook fashion and give examples drawing on the recent empirical literature.

By synthesizing these examples we hope to develop a framework for future empirical studies on corporate governance with two purposes. First, the framework serves to detect the causes of potential estimation biases. Second, it provides suggestions how these problems can be avoided. Our contribution is written as a survey with a broad coverage of econometric problems, an applied view in order to point out practical solutions to these problems, and we pay particular attention to the institutional setting in Germany. 


\section{Introduction}

Corporate governance is the complex system of control mechanisms supposed to influence management behavior in order to guarantee a high value of the owners' equity in the firm. Efficient corporate governance reduces the agency costs resulting from a divergence of interest between the owners and the managers of the firm (BerLE and MEANs 1932, JENSEN and MECKLING 1976).

Understanding corporate governance is important because these agency costs are potentially large, reducing the overall productivity of a firm and, if widespread, of an entire country (BÖRSCH-SUPAN 1999). The heated debate about the "Rhine model" versus the "Anglo-Saxon model" of governance (PORTER 1992, JENSEN 1993) remains unresolved. Unfortunately, theoretical analyses of corporate governance tend to deliver ambiguous answers because there are too many counteracting mechanisms which mask any clear picture (HELLwIG 1997).

Empirical studies of corporate governance are supposed to shed light on the relative weight of these counteracting mechanisms. They usually regress some measure of performance, ideally the firm's equity value or total factor productivity, on measures of the stringency of corporate governance, such as ownership structure, capital structure, the structure of the board and the market for corporate control.

Unfortunately, this is not an easy task. For reasons explained in this survey, empirical studies on corporate governance have more than the usual share of econometric problems. Quite frequently, firm variables are assumed to be exogenous but are actually endogenous; relevant variables are left out; the sample is not selected randomly; and variables are measured with large errors. In all of these cases it will be difficult to identify the influence of corporate governance factors on firm performance.

Aim of this paper is a critical survey of the recent empirical literature on corporate governance with an emphasis on the methodological lessons that can be learned for future empirical research in the field of corporate governance. We structure the paper by four categories of econometric problems that have to be solved in order to infer causal effects of corporate governance: reverse causality, missing variables, sample selectivity, and measurement error in variables. In each section, we briefly describe the econometric problem pretty much in a textbook fashion and give examples drawing on the recent empirical literature. By synthesizing 
these examples we hope to develop a framework for future empirical studies on corporate governance with two purposes. First, the framework serves to detect the causes of potential estimation biases. Second, it provides suggestions how these problems can be avoided.

We are of course not the first who note that empirical studies on corporate governance tend to be subject to a host of econometric problems. A good example is the recent study of HimMELBERG et al. (1999) who discuss in detail estimation biases resulting from reverse causality and sample selectivity problems. Our contribution is written as a survey with a broad coverage of econometric problems, an applied view in order to point out practical solutions to these problems, and we pay particular attention to the institutional setting in Germany.

Section 2 of this paper begins with the problem of reverse causality (or endogeneity). This problem is omnipresent because analyses of the efficacy of corporate control instruments on firm performance require that these instruments are exogenous. In practice, however, it is typical that a deterioration of firm performance precipitates changes in governance. In turn, well performing firms attract investors with equally typical ownership structures and thus corporate governance.

Section 3 addresses the problem of missing variables. This classical econometric problem has particularly interesting consequences in the case of an interaction of product market competition and corporate control mechanisms. We argue that product market competition and corporate governance are partial substitutes (i.e., bad corporate governance structures can be offset by fierce product market competition). Hence, an analysis of corporate governance without explicit consideration of product market competition will fail.

Section 4 analyzes how sample selectivity affects the estimation of corporate governance mechanisms. Also this econometric problem is as frequent as it is serious because most empirical studies analyze only the largest and - among them - only the listed firms. Size and being listed is frequently a function of firm performance, inducing selectivity bias.

Section 5 finishes our list of econometric problems with a discussion of typical measurement errors. Firm performance is hard to measure in practice, particularly during episodes of stress and corporate governance actions. A badly measured dependent variable weakens estimation results due to a low signal-to-noise ratio. On top of this, the usual proxy constructions for corporate governance variables reduce the estimated effects. Both effects contribute to the com- 
mon but - as we will argue - incorrect conclusion that corporate governance mechanisms are overrated in their effect on productivity and firm performance.

These conclusions are summarized in Section 6, augmented by recommendations what can be done in practice in order to obtain better and more precise estimates of the efficacy of corporate governance.

\section{Reverse Causality}

The core task of empirical studies on corporate governance is to explain firm performance by firm-specific variables that describe ownership control. High monitoring costs between shareholders and managers can make ownership control ineffective when the shares are dispersed (GROSSMAN and HART 1980), compared to a situation in which the shares are owned by only a few large shareholders (SHLEIFER and VISHNY 1986). However, the direction of causality between ownership structure and firm performance is not clear: more concentrated ownership can improve firm performance via better monitoring, but good-performing firms could also attract investors. This is an example of structural reverse causality.

JENSEN and MECKLING (1976) argue that the lower the participation of management is in the firm's equity, the higher are the agency costs. High managerial ownership aligns the managers' incentives with the incentives of shareholders (Convergence-of-Interest Hypothesis). Vice versa, managers could hold equity especially in highly-profitable firms which have a high profitability because this increases their wealth (LELAND and PYLE 1977). Causality of ownership and performance is therefore not clear ex ante.

Similar problems arise when an unobserved variable simultaneously determines ownership structure and performance. This case of reverse causality is known as spurious correlation. To illustrate this we borrow an example used by HIMMELBERG et al. (1999). Assume that there are two types of firms: firm $\mathrm{A}$ has a higher degree of market power than firm B. If competition has a disciplining effect on managerial decisions, closer monitoring is required in firm A. In consequence, managers of firm A might receive a higher part of equity to align their interests with those of the other shareholders. However, due to market power firm A shows higher profit rates than firm B. Empirically, we would measure a positive correlation between mana- 
gerial ownership and profitability. ${ }^{1}$ But the estimated coefficient of managerial ownership will reflect only spurious correlation, not a causal relationship.

In these examples, the explanatory variable "ownership structure" is co-determined with the variable to be explained, namely firm performance. In econometrics speak, the explanatory variable is actually endogenous. Without structural assumptions, the impact of this corporate governance mechanism on performance cannot be identified.

More formally, assume that the true model can be written as

$$
\begin{aligned}
& z=\beta x+\varepsilon \text { and } \\
& x=\gamma z+\eta,
\end{aligned}
$$

where $\mathrm{E}(\varepsilon)=\mathrm{E}(\eta)=0$ and $\operatorname{cov}(\varepsilon, \eta)=\sigma_{\varepsilon \eta}, \mathrm{z}$ denotes firm performance and $\mathrm{x}$ ownership concentration. If only the first equation is estimated by OLS, we obtain

$$
\hat{\beta}=\frac{\operatorname{cov}(\mathrm{x}, \mathrm{z})}{\operatorname{var}(\mathrm{x})}=\frac{\operatorname{cov}(\mathrm{x}, \beta \mathrm{x}+\varepsilon)}{\operatorname{var}(\mathrm{x})}=\beta+\frac{\operatorname{cov}(\mathrm{x}, \varepsilon)}{\operatorname{var}(\mathrm{x})} .
$$

The second term can be evaluated by replacing $\mathrm{x}$ with the right-hand side of equation (2.2). We obtain

$$
\operatorname{cov}(x, \varepsilon)=\operatorname{cov}(\gamma z+\eta, \varepsilon)=\operatorname{cov}[\gamma(\beta x+\varepsilon)+\eta, \varepsilon]=\gamma \sigma_{\varepsilon}^{2}+\beta \gamma \operatorname{cov}(x, \varepsilon)+\sigma_{\varepsilon \eta}
$$

It follows that $\operatorname{cov}(\mathrm{x}, \varepsilon)=\frac{\gamma \sigma_{\varepsilon}^{2}+\sigma_{\varepsilon \eta}}{1-\beta \gamma}$. If $\gamma \neq 0$ or $\sigma_{\varepsilon \eta} \neq 0$, the estimated coefficient $\hat{\beta}$ will be biased and inconsistent. The first is true in our first example of structural reverse causality, the second if common unobserved factors are present. In the latter case, the empirically measured correlation between $\mathrm{x}$ and $\mathrm{z}$ is only spurious. Since both cases are very likely, reverse causality is, in our view, the most serious problem in studies on corporate governance.

\footnotetext{
${ }^{1}$ Note that this effect depends on the measure of performance applied here: ceteris paribus, profitability is likely to be higher in firms with market power but not necessarily productivity or productivity growth. For example, JANUSZEWSKI et al. (1999) find a negative impact of market power on the growth of total factor productivity.
} 
The formal description in equations (2.1)-(2.4) is helpful in analyzing the problem. Suppose that negative performance leads to a takeover which results in higher shareholder concentration. Assume further that the new owners replace management which in turn leads to improved performance. In terms of equations 2.1 and $2.2, \beta$ is the impact of shareholder concentration on performance and $\gamma$ the impact of performance on shareholder concentration. According to our assumptions, $\beta$ is positive and $\gamma$ negative. If $\sigma_{\varepsilon \eta}=0$, we know that the covariance of $\mathrm{x}$ and $\varepsilon$ is positive. This implies that the impact of shareholder concentration on performance is overestimated because we neglected the endogeneity of shareholder concentration.

Another good example for the endogeneity problem is the widely-cited study of DEMSETZ and LEHN (1985). They examine the effect of shareholder concentration on a firm's average profit rate in the years 1976-1980. Using cross-section data for 511 US firms they apply the following model:

$$
\operatorname{Return}_{\mathrm{i}}=\alpha+\beta_{1} \log (\mathrm{A} 5)_{\mathrm{i}}+\sum_{\mathrm{j}=2}^{\mathrm{N}} \beta_{\mathrm{j}} \text { Control Variable } \mathrm{ij}_{\mathrm{j}}+\varepsilon_{\mathrm{i}}
$$

"A5" is their central explanatory variable. It denotes the equity share of the five biggest shareholders in the firm. ${ }^{2}$ As control variables they use expenditures for advertising and $R \& D$, firm size, the standard deviation of accounting rates of return and the standard deviation of market rates of return to proxy for the instability of a firm's environment as well as industry dummies. Their main result is that ownership concentration has a negative, although insignificant impact on the firm's average profit rate. DEMSETZ and LEHN attribute this result to the endogeneity of ownership structure: shareholders deciding to alter the ownership structure from concentration to dispersion of shares should do this in awareness of its consequences for loosening control over professional management (DEMSETZ and LEHN 1985: 1174). Therefore, in their view no relationship between ownership concentration and performance should exist.

The study of DEMSETZ and LEHN (1985) exemplifies the approach of a host of other empirical studies examining the influence of ownership structure on performance. MoRCK et al. (1988)

\footnotetext{
${ }^{2}$ DEMSETZ and LEHN (1985) also use alternative measures of management ownership such as the share owned by the top 20 shareholders or a HERFINDAHL index which measures shareholder concentration.
} 
regress firm value measured by Tobin's q on the fraction of shares owned by management using a cross-section of 371 US firms. The main problem with their approach is that their cross-sectional data cannot provide for instruments which are necessary to control for potential endogeneity of ownership. In the same manner MCCONNELL and SERVAES (1990) use a sample of 1173 US firms to explain Tobin's q by the ownership structure of shares. In contrast to MORCK et al. (1988) they have inter-temporal variation in their data because they use two sets of cross-sectional data. Being aware of the problem of potential spurious correlation they determine the robustness of their results by adjusting all variables for their industry mean. However, MCCONNELL and SERVAES do not check the problem of structural reverse causality - probably due to the lack of valid instruments. LEECH and LEAHY (1991) use a sample of 470 listed UK firms. They directly address the problem of endogeneity by regressing ownership structure on firm age, firm size and a measure of firm-specific risk. But there remain two problems with their approach. First, they do not explain firm performance and ownership structure simultaneously. Second, their explanatory variables are also likely to be endogenous. Thus they cannot avoid reverse causality.

Compelling evidence for an endogeneity problem created by unobserved common factors to both right-hand side and left-hand side variables is presented by HIMMELBERG et al. (1999). This example is particularly helpful because it shows that panel data are extremely important in getting rid of this second cause of endogeneity. To solve the endogeneity problem HIMMELBERG et al. use firm panel data from 1982-1992 to assemble an unbalanced panel with about 600 US firms. They explain the level of managerial equity shares $m_{i t}$ as follows:

$$
\mathrm{m}_{\mathrm{it}}=\beta_{1} \mathrm{x}_{\mathrm{it}}+\gamma_{1} \mathrm{u}_{\mathrm{it}}+\varepsilon_{\mathrm{it}}
$$

where $x_{i t}$ are observable and $u_{i t}$ unobservable firm characteristics. Assuming that the unobservable firm characteristics $u_{i t}=u_{i}$ are constant over time, they calculate both pooled and fixed-effect estimators. In the pooled regression managerial ownership is explained by expenditures for $R \& D$ and advertisement, firm size and firm's idiosyncratic risk. They calculate several variants of fixed-effect estimators. Then most coefficients change sign or become insignificant while the adjusted $\mathrm{R}^{2}$ rises significantly. This suggests that in the pooled OLS regression the error term is correlated with explanatory variables leading to biased coefficients. 
SHORT (1994) provides an excellent survey of further empirical studies. She concludes that most studies are limited by the use of cross-sectional data because only panel data allow to fully capture the dynamic interactions of firm-specific variables.

\section{Lessons}

Theoretical considerations and empirical evidence show that no conclusions about the impact of any corporate governance mechanism on firm performance can be made without considering the problem of reverse causality. Two things can be learned for future empirical research:

- Panel data: Cross-sectional data do not allow to correct for unobserved firm heterogeneity. Panel data are a necessary condition for the identification of any singular corporate governance mechanism because panel data can provide for instruments that are not available in cross-sectional data. For Germany, balance sheet data in panel format are commercially available, among others, from Hoppenstedt/Germany (Balance Sheet Database) ${ }^{3}$ or Primark/United Kingdom (Worldscope Global Researcher).

- Take the unobserved into account: When unobserved firm characteristics are correlated with the exogenous variables, estimated coefficients will be biased. Estimating fixedeffect models or models in first differences can help to solve this problem. However, when the unobserved firm characteristics are not constant over time, this econometric trick does not work because firm-effects cannot be subtracted out of the specification (e.g. by calculating first differences). The only way out is to reduce the unobserved part of our model and to collect time-series information on all relevant firm-specific variables. Panel data on ownership structures in Germany are, for example, commercially available from Bureau van Dijk/Belgium (Amadeus) or Hoppenstedt/Germany (Company Structure Database). ${ }^{4}$

Thus the case for panel data is strong. In time-series data, part of the variation in the exogenous variables can take place within each firm (within variation), part of it between all firms (between variation). When a cross-sectional sample is used, we cannot differentiate between these two forms of variation. This is important, however, in the presence of unobserved firm heterogeneity. If unobserved firm heterogeneity is correlated with exogenous variables, in a pooled regression estimated coefficients will be biased. Only panel data allow to separate

\footnotetext{
${ }^{3}$ Bilanzdatenbank.

${ }^{4}$ Konzernstrukturdatenbank.
} 
within-firm variation from between-firm variation. In the case of unobserved firm heterogeneity, fixed-firm-effect estimators pick up between-firm variation.

Unfortunately, even with panel data two problems remain. First, estimating fixed effects does not explain why there is variation between firms. For corporate governance this could be of particular interest because we want to know which firm-specific arrangements improve performance. The true source of performance improvement can only partly be identified by interpreting within-estimators. Second, as argued by HIMMELBERG et al. (1999), unobserved firm characteristics can vary over time. If this is the case, estimated coefficients will be biased and inconsistent. Therefore, more model structure is required to better understand the process how corporate governance influences performance and how in turn corporate governance mechanisms are influenced. DENIS and SARIN (1999) go a first step in this direction by challenging the commonly assumed persistence of a firm's ownership structure. They show that ownership structure and composition of the board of directors exhibits significant intertemporal variance. Changes in ownership structure are related to management turnover, stock performance or takeover threats.

For Germany, using a large panel of listed and non-listed firms KÖKE (1999) shows that ownership structures exhibit significant variation over time, especially in large listed firms. Any study analyzing the effect of ownership structures therefore must include both financial data and ownership data in panel format.

But even including all firm-specific variables in panel format does not solve the problem that potentially all firm-specific variables are endogenous. Uncontroversial instruments, crucial for identification, are those which are determined outside the firm and affect the firm. Prime candidates are macroeconomic variables or government regulations.

NiCKELL and NiCOLITSAS (1999) investigate the impact of increases in financial pressure, measured as the ratio of interest payments to cash flow, on company behavior. They find that an increase in financial pressure has a large negative impact on employment, a small negative impact on pay rises and a minute positive impact on productivity. To cope with potential endogeneity of firm-specific financial pressure NICKELL and NICOLITSAS apply a set of instruments: deep lags on employment, output, wages, and the capital stock. For their key financial variable, financial pressure, they make use of substantial exogenous shifts in interest rates which have been instituted by government policy over the sample period. 
ZINGALES (1998) shows how a change in the regulatory environment can identify firm processes. ZINGALES examines the exit behavior in the US trucking industry following major industry deregulation in 1979 initiated by the Carter administration. Deregulation significantly lowered barriers to entry and allowed for increasing competition that was largely unexpected. Thus capital structure is not likely to have been chosen optimally beforehand. ZINGALES uses the change in competitive pressure to identify the role of different capital structures on the exit behavior of firms. On a set of 889 trucking firms he examines the survival until 1985 with the following probit model:

$$
\text { Probability }\left(\text { Survival }_{\mathrm{i}}^{1985}\right)=\mathrm{f}\left(\mathrm{X}_{\mathrm{i}}^{1977}, \text { Leverage }_{\mathrm{i}}^{1977}\right)+\varepsilon_{\mathrm{i}}
$$

The variable of interest is the firm's leverage in 1977, i.e. before deregulation. Other factors potentially influencing the firms' survival are various measures of efficiency $\left(\mathrm{X}_{\mathrm{i}}^{1977}\right)$. Among these are the level of intangibles (as a fraction of total assets), firm size and return on sales. Leverage thus should catch any separate effect on survival other than efficiency. ZINGALES' results indicate that highly-leveraged firms had a reduced chance of survival after deregulation. A reason for this may be that they had to curtail good investments.

Other good examples for the use of industry deregulation for identification purposes are the studies of KANG (1998) for the US textile industry, KOLE and LEHN (1997) for the US telecommunication and electric utilities industries, KOLE and LEHN (1999) for the US airline industry and COLE and MEHRAN (1998) for the US thrift industry. For Germany, the history of deregulation is still short. Only recently the markets for telecommunication and energy were opened to competition. The enactment of the Single European Market in 1992 might represent a useful instrument in panel studies, but only when it occurred as an exogenous shock. ALLEN et al. (1998) find that its enactment had a major impact on tariffs which in turn drove competition within the European Union.

The development of new estimation techniques has eased a solution of the identification problem. General Method of Moments (GMM) estimators allow the researcher to use lagged values of the endogenous variable as instruments also in non-linear specifications such as the one used by ZINGALES (1998). Examples for the use of the GMM technique are the studies of NICKELL et al. (1997) and JANUSZEWSKI et al. (1999). JANUSZEWSKI et al. examine the effects of product market competition and corporate governance on productivity growth. Using an 
unbalanced panel of listed and non-listed German manufacturing firms they find that firms in more competitive industries tend to see higher growth rates of total factor productivity. Concentration in the ownership structures, in turn, have a weakly negative influence. Their results concerning the disciplining role of competition support those of NICKELL et al. obtained for the United Kingdom but stand in contrast to the positive role of share concentration that NiCKELL et al. find. Both studies are good examples how the endogeneity problem can econometrically be addressed without identifying exogenous events.

\section{Missing Variables}

A second and well-known econometric problem plaguing empirical studies of corporate governance variables occurs when explanatory variables are missing in the estimated model. This occurs in two forms. First, for reasons of data availability typical in the entire industrial organization research, this literature features a more than normal number of estimated equations in which key explanatory variables are not available for inclusion. Second, knowing little about functional forms, the commonly employed linear specifications imply, if counterfactual, missing higher order terms in the equation that has been estimated.

A particular interesting example of a very frequently missing variable in the existing empirical corporate governance literature is product market competition (BAILY and GERSBACH 1995). For example, more intense competition in the product markets should increase pressure on management because profits can shrink and, in consequence, non-performing managers could get fired (HART 1983). ${ }^{5}$ However, pressure resulting from high corporate debt burdens could substitute for pressure from intense competition as shown by NICKELL et al. 1997. Hence, the interaction between product market competition and corporate governance mechanisms becomes important.

A prominent example for the second case is again the study of DEMSETZ and LEHN (1985). In their model shareholder concentration is supposed to influence the average profit rate. Their specification imposes the restriction that this influence is linear in nature. But this is not consistent with theory. JENSEN and MECKLING (1976) argue that managerial ownership should

\footnotetext{
${ }^{5}$ This result is not uncontroversial in the theoretical literature. SCHARFSTEIN (1988) shows that Hart's results depend on the extent of managers ' assumed risk aversion. In a similar model but with a different utility func-
} 
have a positive impact on performance. FAMA and JENSEN (1983) show that high managerial ownership stakes could make managers too risk-averse. Hence, performance should be lower the higher are the managerial equity stakes (Managerial-Entrenchment Hypothesis). DEMSETZ and LEHN'S model does not allow for a non-linear influence of ownership. As we know, this could be corrected by using a polynomial form in the model, e.g. managerial ownership could enter the regression model in a linear and a quadratic term. In most studies the quadratic and higher order terms are left out, generating a left-out variable bias.

More generally, if the true structure of the model is

$$
\mathrm{y}=\alpha+\beta \mathrm{x}+\gamma \mathrm{z}+\varepsilon
$$

but the regression leaves out the variable $\mathrm{z}, \beta$ is estimated by

$$
\hat{\beta}=\beta+\gamma \frac{\operatorname{cov}(\mathrm{x}, \mathrm{z})}{\operatorname{var}(\mathrm{x})}
$$

which is unbiased only if (1) $\gamma=0$ or (2) the covariance of $\mathrm{x}$ and $\mathrm{z}$ is zero.

This textbook analysis generalizes to the multivariate case and may be used to sign the bias and to assess its relevance. Assume that $\mathrm{y}$ is the firm's profit, $\mathrm{x}$ is the ownership of managers in the firm's equity and $z$ measures the degree of competition the firm is facing in its product markets. Assume further that higher competition leads to lower profits, i.e. $\gamma$ is negative, and that competition reduces agency costs. Then managers can be offered a lower equity share in the firm to align their incentives compared with a situation in which the firm has substantial market power. This means that $\operatorname{cov}(\mathrm{x}, \mathrm{z})<0$. If no measure of competition is included in the regression, the impact $\beta$ of manager's equity on performance will be overestimated.

Taking the DEMSETZ and LEHN (1985) example, we also know the sign of the bias from a priori information. The theoretical studies of JENSEN and MECKLING (1976) and FAMA and JENSEN (1983) predict different impacts of managerial share ownership on performance. But since FAMA and JENSEN (1983) predict a negative relationship only for higher values of mana-

tion SCHARFSTEIN obtains the opposite result: more competition increases managerial slack. HERMALIN (1992) shows that if agency goods are normal goods competition decreases agency costs. 
gerial ownership we can expect an inverse U-shaped relationship. Leaving out the quadratic term will therefore cause the coefficient of the linear ownership variable to be underestimated. MORCK et al. (1988) provide evidence for this hypothesis. They regress Tobin's q as a measure of performance on managerial ownership using a piecewise linear regression. They find that the relationship is non-linear with turning-points at 5 percent and 25 percent. Below 5 percent the slope coefficient is positive, between 5 percent and 25 percent negative, and over 25 percent again positive. MCCONNELL and SERVAES (1990) confirm this result using a polynomial specification for managerial ownership. Hence, the result of DEMSETZ and LEHN (1985) who show that managerial ownership has no significant impact on performance can be due to an incomplete model.

Another difficulty is how a non-linear influence of right-hand side variables is detected. The way chosen by MORCK et al. (1988) is to assume a priori that 5 and 25 percent represent the break-off points for the piecewise regression model. Since the theoretical literature does not provide us with this very specific kind of information an econometrically better approach would be to estimate the break-off points themselves.

The general problem is that we do not know which variables are left out. If only one variable is missing in the model - for example because we do not have sufficient data on it - we can predict the direction of bias only by using additional assumptions which themselves might not be testable. If more than one variable is omitted, it becomes more difficult to predict the direction of bias (GREENE 1997: 402). For example, if the firm's leverage also has a disciplining effect on managers and is omitted from the model, the covariance of competition and ownership must be predicted but net of the effect of leverage. Here economic intuition soon will become unreliable.

This problem is particularly salient because the data requirements for empirical corporate governance analysis are high. As shortly discussed in the introduction, the corporate governance literature enumerates six main different channels how managers can be disciplined. These are: ownership structure (JENSEN and MECKLING 1976, GRossman and HART 1980), capital structure (JENSEN 1986, ZWIEBEL 1996), board structure (JENSEN 1993, BRICKLEY et al. 1988, YERMACK 1996), management compensation (JENSEN and MURPHY 1990, KAPLAN 1994 a/b), product market competition (BAILY and GERSBACH 1995, NICKELL et al. 1997) and the 
takeover market (JENSEN and RUBACK 1983, FRANKS and MAYER 1995). ${ }^{6}$ Let us further exemplify the missing variables problem by discussing specific studies dealing with the influence of ownership structure on firm performance.

POUND (1988) argues that the quality of monitoring depends on the type of investor. Institutional investors like banks or insurance companies might have business relations with the firm they ought to monitor which they might not want to endanger by too harsh monitoring. In so far private investors might be better monitors. On the other hand, institutional investors like pension funds that have no business relations with the firm could be more disciplining (POUND 1988). While the empirical evidence is still preliminary, early studies indicate that pension funds have a significant influence on changes of the corporate charter (GORDON and POUND 1993, SMITH 1996). ${ }^{7}$

A good example on the interaction of different governance mechanisms is the study of MCWILLIAMS and SEN (1997). They investigate whether managerial shareholdings have a negative effect on the market valuation of anti-takeover amendments of the corporate charter or whether their membership on the board has a separate effect. In a first step MCWILLIAMS and SEN show that the higher the managerial holdings the more negative the stock market's reaction. But they argue that managers' board membership should have a separate effect on the reaction of the market. In particular, if a manager holds equity and in addition sits on the board, the stock price should fall even more because managers would have much more power in the corporation. Just managerial stock ownership should not matter. Formally, if the probability for board membership is correlated negatively with the market reaction and if this probability is positively correlated with managerial equity, the impact of managerial equity on the market reaction will be underestimated. In other words, if the true impact of managerial ownership on the stock price reaction is zero but a mixed impact of board membership and equity ownership is measured by only using managerial ownership in the model, the true influence of equity ownership cannot be identified. For 265 US firms from 1980 to 1990 they run the following second regression:

$$
\text { Stock Price }_{\mathrm{it}}=\alpha+\beta_{1} \text { Board Shareholdings }_{\mathrm{it}}+\beta_{2} \text { Nondirector Shareholdings }_{\mathrm{it}}+\varepsilon_{\mathrm{it}}
$$

\footnotetext{
${ }^{6}$ See SHLEIFER and VISHNY (1997) for an in-depth review of the literature on corporate governance mechanisms.

${ }^{7}$ See BLACK (1998), KARPOFF (1998) and DEL GUERCIO and HAWKINS (1999) for critical surveys.
} 
While the coefficient $\beta_{1}$ remains significantly negative, the coefficient $\beta_{2}$ is close to zero. Thus the results form the first regression were misleading: it is not managerial share ownership itself that causes the negative stock market reaction to these charter amendments. Rather it is the managers' membership on the board.

NiCKELL et al. (1997) examine the simultaneous impact of product market competition, capital structure and ownership structure on the firm's productivity growth $\Delta\left(y_{i t}-k_{i t}\right)$. Using data on 580 UK manufacturing firms from 1982 to 1994 they run the model:

$$
\Delta\left(y_{i t}-k_{i t}\right)=f(\text { Employment, Capital Stock, Shareholder Control, Competition })+\varepsilon_{i t}
$$

Shareholder control is defined as the probability that the biggest shareholder will win a vote under the assumption that all the other shareholders vote independently (CUBBIN and LEECH 1983). Their measure of competition is the inverse of ex post rents (profits less capital costs) normalized on value-added. Financial pressure is measured by interest payments normalized on cash flow. They find that all three factors improve total factor productivity growth but that shareholder control and financial pressure can substitute for competition. Formally, if competition had been neglected in the model, the impact of shareholder control would have been underestimated because the covariance of shareholder control and competition is negative and competition itself has a positive influence on productivity growth.

\section{Lessons}

There are several lessons from these empirical studies. First, if theory suggests that particular variables have a non-linear influence on firm performance, the model must include polynomial terms of the relevant variables. Alternatively, piecewise regressions can be run. Forcing variables to have a linear impact can bias the estimated coefficients. Second, the influence of a particular corporate governance mechanism generally will not be identified if other relevant mechanisms are omitted from the model. Coefficients will be biased and inconsistent if governance mechanisms can substitute or complement each other. This is, however, very likely for any firm-specific variable.

We have some clear requirements for data on hand. Earlier studies were limited through data availability. This has changed. The following specific data are required:

- Ownership data: shareholder type (e.g. managers, non-managing individuals, institutional shareholders, government), size of share blocks 
- Financial data: debt structure (i.e. long-term versus short-term, bank versus industry credit, outside versus inside financing)

- Board structure: composition of the board (size, fraction of insiders or bankers, equity positions of board members, union representation)

- Competition measures: market power (number of competitors, industry-specific Herfindahl indices, product-specific regulation)

- Takeover activity: numbers of successful and not successful hostile takeover attempts.

If any of these variables are not used in estimation, a bias in coefficients will be likely. The problem with these requirements is that usually our data actually had been collected for other purposes. Therefore they are often incomplete over time and also do not contain the required details. This can significantly reduce panel size.

Sources for some of these data have already been enumerated in section 2. As to data on ownership and board structures, balance sheet data are often not sufficient. The same is true for data on competition: for the researcher the degree of competition is generally observable only ex post (e.g. by using individual market shares as proxies). Then also competition is neglected which did not manifest itself (e.g. the threat of market entry). For Germany, competition data are available from the Antitrust Commission (Monopolkommission). The main problem with these competition data is that they are industry-specific and must be matched to individual firms. ${ }^{8}$ An additional limitation with this approach is that these competition data are available mainly for the manufacturing sector, but not for service industries.

Concerning ownership data on German companies the situation is better. As mentioned in section 2, such data are available in panel format. But a significant constraint is that before 1994 these data are available only in print format. Besides, only from 1995 on individual share stakes exceeding 5 percent must be disclosed to the public. Also the recent Law on Transparency and Control (KonTraG) leaves much room for firms to circumvent this disclosure requirement (BECHT and BÖHMER 1999).

Compared with the United States, data availability on managerial remuneration is much less developed. In an attempt to improve investor relations, the largest German enterprises are

\footnotetext{
${ }^{8}$ We come back to this issue in section 5 .
} 
starting to disclose voluntarily information on this element of corporate governance (CONYON and SchwALBACH $1997 \mathrm{a} / \mathrm{b}$ ). Almost prohibitive is also the effort required for tracking managers' careers and the history of the board structure because only print data are available. However, a reliable source for data on the German board of directors (Aufsichtsrat) seems to be the Guide through German Companies (Aktienführer) from former Hypobank.

\section{Sample Selectivity}

Most empirical studies on corporate governance analyze only the largest and - among them the listed companies. These companies are also likely to be the most profitable firms in the market. MorCK et al. (1988), AgRAWAL and KNOEBER (1996) and CHO (1998), for example, all consider only firms from the Fortune 500 in the US. Most studies on Germany also examine the top-performing firms (e.g. CABLE 1985, NiBLER 1995, SEGER 1997). But performance is the variable that corporate governance is supposed to influence: these samples are obviously selected by the endogenous variable. Thus, most studies of corporate governance are likely to have a sample selection bias.

Take the example of management compensation, a governance mechanism which recently attracts increasing attention (JENSEN and MURPHY 1990). If compensation is tied to performance, managers should become more focused on the respective performance measure. Empirical studies face the problem that data on management compensation are available only for those firms which enacted compensation programs. But these enterprises tend to be wellperforming firms, often listed on the stock exchange. Hence, a selection bias is likely here.

More formally, estimated coefficients are unbiased only if the expectation of the error term given the exogenous variables is zero. In the model

$$
\mathrm{y}=\beta \mathrm{x}+\varepsilon
$$

the condition $E(\varepsilon \mid x)=0$ must be satisfied for $\hat{\beta}$ to be unbiased. If the sample is not randomly selected, i.e. if the probability for firms being in the sample is correlated with the endogenous variable, this condition does not hold.

To illustrate this, suppose that we have data for $\mathrm{y}$ only above a certain threshold $\mathrm{y}^{*}$. Here $\mathrm{y}$ might represent firm performance and $\mathrm{x}$ the concentration of share ownership, see Figure 1. 


\section{Figure 1: Estimation Bias due to Sample Selection}

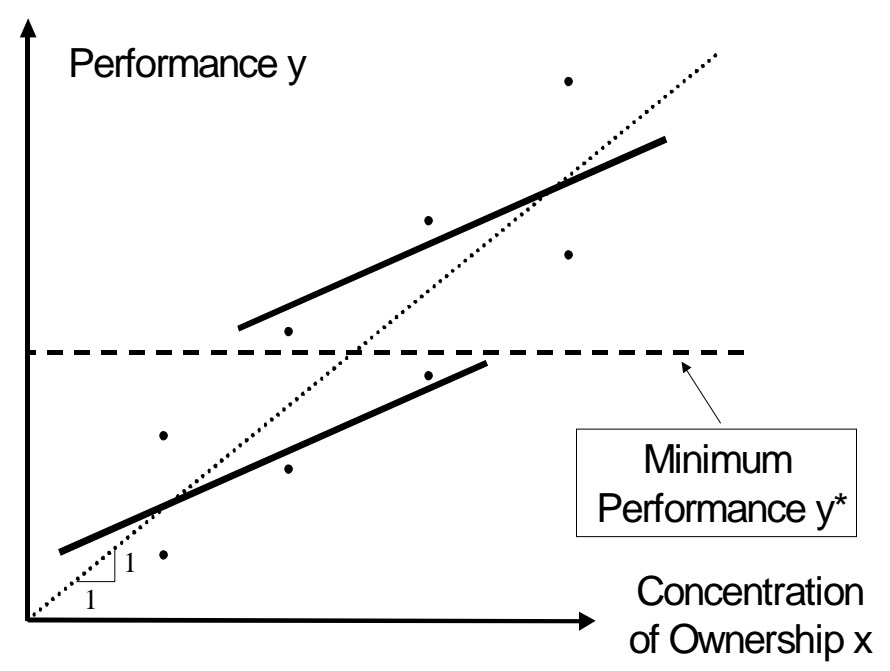

The true slope coefficient is $\beta=1$ and is depicted by the dotted line. We see that by excluding lower values of $y$ from the regression - e.g. below a minimum performance of $y^{*}-$ we systematically exclude residuals that are negative at low values of $x$. Thus, on average the error term will be positive given low values of $\mathrm{x}$. But this implies a downward bias of $\hat{\beta}$ for performance values above $\mathrm{y}^{*}$ (bold lines). More generally, the direction of bias depends on the covariance of $\mathrm{x}$ and $\varepsilon$. If we knew $\mathrm{E}(\varepsilon \mid \mathrm{x})$, we could include it in the regression, resulting in unbiased estimates - hence sample selectivity is a special case of omitted variables. ${ }^{9}$

In particular, if we explain performance by the concentration of ownership, the impact will be underestimated when we use only firms with 'high' performance. 'Low' performers might not be in the sample because they were too small in size and hence were not required to report financial data. Our estimate with the 'high' performers would be misleading because not ownership structure forced the coefficient to be smaller than one but firm size. The true source of influence on performance would not be identified.

To our knowledge, all empirical studies on corporate governance in Germany suffer from the econometric problem of selection bias. Table 1 lists the most recent of them and compares the selection criteria applied for sample construction.

\footnotetext{
${ }^{9}$ See MADDALA (1983) on the econometrics of limited dependent variables.
} 
Table 1: Comparison of Criteria for Sample Selection

\begin{tabular}{ll}
\hline STUDY & SAMPLE SELECTION \\
\hline CABLE (1985) & 48 out of the 100 largest companies in 1970 (only AG) \\
NiBLER (1995) & 158 out of the 200 largest companies in 1992 (mostly AG, a few GmbH) \\
GORTON and SCHMID (1996) & Two cross-sections: \\
& $\begin{array}{l}\text { 1. } 88 \text { out of the } 100 \text { largest companies in } 1974 \text { (only AG) } \\
\text { 2. } 57 \text { out of the largest companies in } 1985 \text { (only AG) }\end{array}$ \\
\hline CHIRINKO and ELSTON (1996) & $\begin{array}{l}270 \text { companies (only AG) that were continuously traded on the stock } \\
\text { exchange between 1965-1990 } \\
\text { SEGER (1997) }\end{array}$ \\
$\begin{array}{l}144 \text { companies (only AG) that were continuously traded on the stock } \\
\text { exchange between 1990-1992 }\end{array}$ \\
$\begin{array}{l}48 \text { companies (only AG) that were continuously traded on the stock ex- } \\
\text { change between 1973-1993 }\end{array}$ \\
\hline
\end{tabular}

As can be seen from Table 1, in almost all cases only companies in the form of the Aktiengesellschaft $(A G)$ (public company with limited liability) are selected for analysis. In addition, often a size criterion is applied since only the largest stock companies are used (CABLE 1985, Nibler 1995, Gorton and Schmid 1996). The studies of ChIRINKo and Elston (1996), SEGER (1997) and WENGER and KASERER (1997) demand yet another criterion: the companies selected must have been continuously traded on the stock exchange, in the case of CHIRINKO and ELSTON for 25 years in total. As understandable the selection of large companies might be - for example in the light of publication requirements (and hence availability of sufficient information) which are the strictest for the largest companies - in general these selection criteria potentially bias estimation results. We try to show this with some intuitive illustrations.

Firm behavior influences the probability that a particular firm will be in a sample for corporate governance analysis. If a firm exits its product market, for example due to bankruptcy or a merger, it will drop out of our sample. If a firm goes public, it will be more likely to be in our data set because we often focus on firms listed on the stock exchange. Hence, both decisions - market exit and listing - influence the probability to be in the sample.

The firm's market value is often used as endogenous variable (e.g. MoRCK et al. 1988, MCCONNELL and SERVAES 1990). But a precondition for this is that a market value for each firm is available. This is fulfilled only for firms listed on a stock exchange. Non-listed firms must be neglected. If the decision to go public depends on performance, the probability for a firm to be in the sample will be influenced by the endogenous variable. In this case parameters will be biased and inconsistent. Assuming that performance is irrelevant for the listing decision certainly is a strong assumption. 
In Germany market capitalization was about 28 percent of GDP in 1996, while it was 114 percent in the US (OECD 1998). This simple comparison shows that incentives to go public might be significantly different between countries. Even within Germany only a comparatively small number of companies decided to have their shares traded. Out of 2300 public companies with limited liability (AG) only about 500 were publicly traded. About 400,000 private companies with limited liability $(\mathrm{GmbH})$ make the majority of limited corporations in Germany (KÖKE 1999). Hence, it is likely that the decision to go public is affected by possibly not observable firm-specific variables or institutional arrangements like the strictness of disclosure rules. In turn, the decision on the legal form is likely to be influenced by regulations concerning co-determination (HOPT 1998) and regulations concerning corporate institutions like the board of directors (Aufsichtsrat) (STEINER 1998). This is a problem if the same variables simultaneously influence performance.

PAGANO and RÖELL (1996) suggest that a strong incentive for listing is a strong need of external funding. In turn, this could be generated by good investment opportunities. The probability of being in the sample could be determined as depicted in Figure 2.

\section{Figure 2: Causes for Selection Bias}

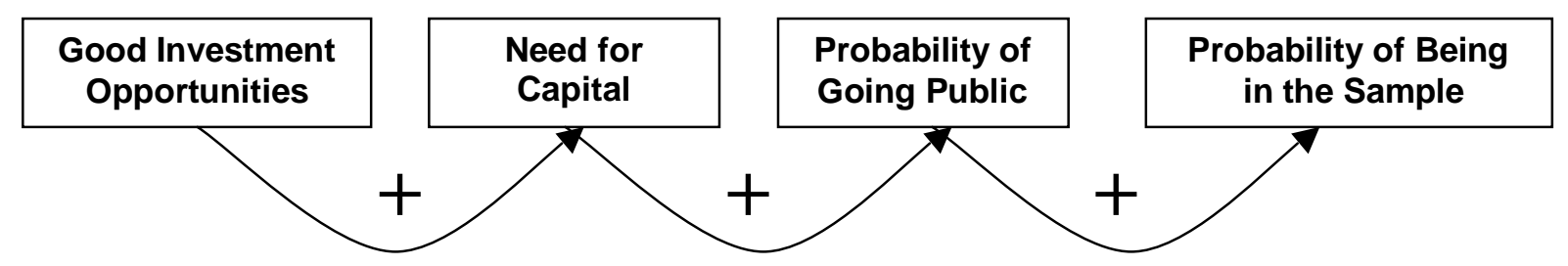

Similarly, if investment opportunities of firms that are already listed on the stock exchange increase, their market value will rise. In both cases the probability of being in the sample will be higher, when our sampling criterion is top-performing firms listed on a stock exchange. Formally, the correlation between the error term and the exogenous variable on average is positive. With a positive influence of investment opportunities on performance the estimated coefficient is biased upward. Hence, the impact of ownership concentration will be mismeasured. In light of this probably all the studies shown in Table 1 suffer from this problem.

The study of HOLDERNESS and SHEEHAN (1988) is an example how to appropriately address sample selectivity. For their analysis they use only firms listed either on the NYSE or AMEX. To check whether there is a selection bias they replicate all estimations on a random sample 
from all firms in the 1980 Spectrum. ${ }^{10}$ Showing that estimation results from both samples are generally the same they conclude that the original sample is not biased.

Besides the decision on listing, the decision to exit a market can bias a sample. Often researchers eliminate firms from their data set for which they do not have a performance history over the whole sample period - e.g. due to market exit, merger or reporting failure - in order to obtain a balanced panel. However, sampling data for surviving firms only leaves them with the top- or well-performing firms; losers are eliminated. Thus, balanced panels in general are probably biased. In light of this, the studies of CHIRINKO and ELSTON (1996), SEGER (1997) and WENGER and KASERER (1997) are likely to suffer from this kind of selection bias. ${ }^{11}$

A good example that uses an unbalanced panel is the study of HIMMELBERG et al. (1999). They collected data for 600 firms from 1982 through 1992. When a firm dropped out in a particular year, they kept the performance history of the firm. Nevertheless, sample bias also occurs when the exit decision is determined by the endogenous variable which in their case is firm performance measured by Tobin's q. HIMMELBERG et al. report that a simple probit model for exit refers to size as the principal explanatory variable for exit, not firm failure. They conclude that selection bias is unlikely in their sample.

Economic intuition tells us that exit decisions are probably strongly correlated with corporate governance failure. If a firm exited the market, we would assume that this is important information about the firm. Not using this information means to include it in the error term. Therefore, firm decisions on market exit or listing are important vehicles for identification.

\section{Lessons}

Sampling bias can be corrected by running an expanded model. The extension essentially models $\mathrm{E}(\varepsilon \mid \mathrm{x})$. However, in order to model $\mathrm{E}(\varepsilon \mid \mathrm{x})$ in the corporate governance context, we need to collect the following data:

- Listing decision (IPO): data for listed and non-listed firms irrespective of the legal form of the firm, time-series data for the process of going public.

\footnotetext{
${ }^{10}$ The only additional criterion they use is that these firms must be in one of the manuals of Moody's.

${ }^{11}$ For an empirical study on the US see for example MURALI and WELCH (1989). They require that the firms in their sample existed continuously during the years 1977-1981.
} 
- Legal form decision: data for all companies with limited liability, i.e. for private and public companies. In case of Germany, we need data on public companies with limited liability $(\mathrm{AG})$ and private companies with limited liability $(\mathrm{GmbH})$.

- Market exit decision: data on mergers and acquisitions (M\&A) or bankruptcy e.g. from press news. In case of missing values we have to verify the current firm status. Timeseries data for the process of exiting the market.

Whereas a number of German data bases contains information on large and listed companies there is only a few which include data on non-listed companies. For example, Worldscope Global Researcher from Primark contains about 500 German companies, but only 16 percent of them in the legal form of the GmbH. The Bonner Sample (Bonner Stichprobe), a database designed for scientific analyses, contains no data on GmbHs at all. Coverage is better in the Balance Sheet Database from Hoppenstedt and Amadeus from Bureau van Dijk, although the latter is quite limited by the number of variables it contains.

The advantage of having a number of non-listed companies is connected with some complications. Although disclosure requirements in essence are the same for all legal forms of large companies with limited liability ( $\$ 266 \mathrm{ff}$. HGB), they are less strongly enforced for non-listed firms. In addition, information about the status of a company (bankruptcy, voluntary liquidation, change in the legal form or the name etc.) officially are available only from courts (Handelsregister) which are accessible only locally at the place of registration of a particular firm. One way to circumvent this institutional obstacle and to obtain information on firm status under reasonable costs is to conduct a survey among sampled firms, most simply by telephone. Of course, in case of liquidation without succession this strategy is not going to work. With this broad set of information on hand the researcher can apply common econometric techniques to correct for selection bias. Assume that firm performance has a truncated distribution (see Figure 3). 


\section{Figure 3: Truncation of the Endogenous Variable}

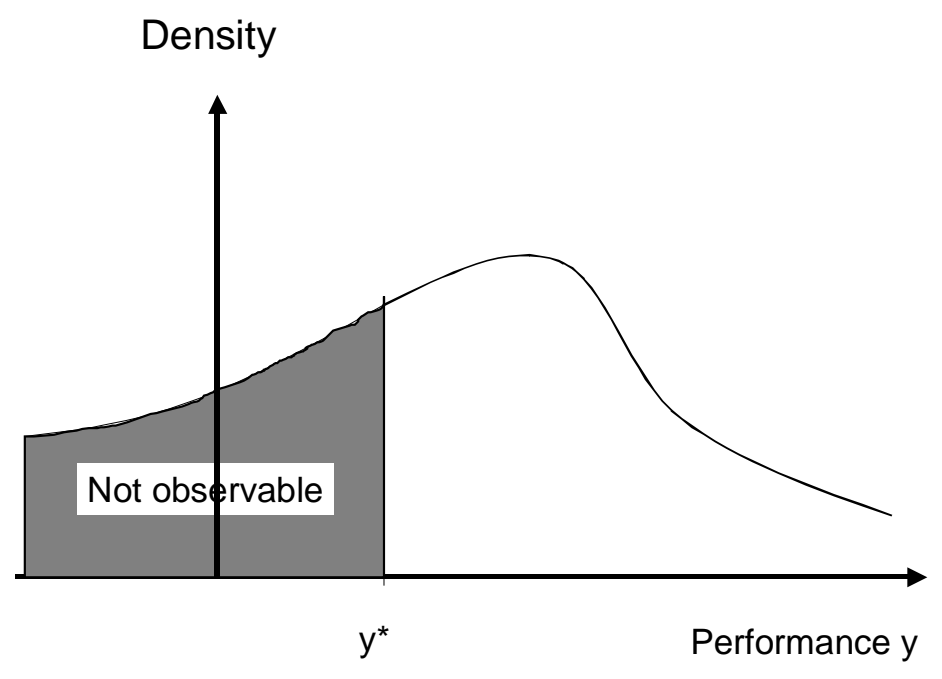

The distribution is truncated at $\mathrm{y}=\mathrm{y}^{*}$. No information is available on firms below minimum performance $\mathrm{y}^{*}$. Performance is observed conditional on the probability that the particular firm belongs to the sample. If we do not use this information, estimated coefficients will be biased and inconsistent. One way to correct this is to calculate the inverse Mills ratio. This ratio measures the probability that firm performance is in a particular range, given this performance value is above the minimum performance level (HECKMAN 1976). In a second step, the inverse Mills ratio is used as a regular regressor. Since this ratio is probably endogenous we must explain it using information about firm exit as instrumental variables. Note that a naive application of the HECKMAN procedure generates problems of its own. Other more recent techniques to deal with selection bias can be found in VERBEEK and NIJMAN (1996).

When maximum likelihood is applied, the probabilities for particular performance values need to be weighted individually with the probability of a performance value to be above the truncation limit. Technically, the white area below the density function in figure 3 must be scaled to one.

The main lesson for empirical studies on corporate governance is that we need more firmspecific data which shed light on the sampling process. This is not an easy task since we usually use data that were collected for other purposes and hence are incomplete for our means. 


\section{Measurement Error in Variables}

Measurement error is the fourth in our list of plagues to empirical corporate governance studies. This includes mismeasurement of the endogenous as well as the exogenous variables.

Corporate governance has the purpose to improve firm performance. However, it is not entirely clear how firm performance ought to be measured. Take the example of takeover studies. Economic theory suggests that the market for takeovers can serve as a corporate control device (JENSEN and RUBACK 1983, FRANKS and MAYER 1995). If firm value is lower than the expected value which can be achieved under a different management team, this signals that a corporate takeover followed by an exchange of management could improve firm value (JENSEN 1988). ${ }^{12}$ The first empirical problem here is that in practice the true market value is particularly hard to measure in times of a takeover due to often erratic variation, and other corporate performance measures are not highly correlated.

Measurement error in the endogenous variable does not cause estimated coefficients to be biased because the error term catches this additional variation, but the estimation results are likely to be weakened due to a low ratio of signal-to-noise. The additional variation may lead to insignificant and unusable estimation results. Estimated effects of corporate governance have a larger range of uncertainty than they have in reality.

As opposed to measurement of the endogenous variable, measurement error in exogenous variables causes coefficient estimates to be biased and inconsistent. This is likely in particular for those variables which firms are not required to submit to the public. Competition measures again are a good example. As discussed in section 3, it is not easy to measure how competitive a market is. In the industrial organization literature, usually ex post measures like individual market shares, rents $^{13}$ or price mark-ups and the elasticity of market demand are used. But since we cannot observe marginal costs and prices are only reported jointly with the amount of goods sold (i.e. by sales), we have only vague information on price mark-ups. Also, market shares are probably measured with a bias since we know only aggregate firmspecific sales, but not firm-specific sales for individual markets for which a firm produces.

\footnotetext{
${ }^{12}$ A problem with this argument is that the old management teams could enact the changes themselves. In addition, the old management team should generally have much better information about its company.

${ }^{13}$ JANUSZEWSKI et al. (1999), for example, define rents as total sales less costs of labor and capital.
} 
More formally, take the simple case with one regressor. Assume that the true regression model is $y=\beta x^{*}+\varepsilon$ and the true $x^{*}$ is measured with error $v$. We observe $x=x^{*}+v$ and measure $\beta$ with

$$
\hat{\beta}=\frac{\operatorname{cov}(x, y)}{\operatorname{var}(x)}=\frac{\operatorname{cov}\left[x^{*}+v, \beta x^{*}+\varepsilon\right]}{\operatorname{var}(x)} .
$$

Expanding the covariance by adding and subtracting $\beta v$ we obtain

$$
\hat{\beta}=\frac{\operatorname{cov}\left[x^{*}+v, \beta x^{*}+\beta v-\beta v+\varepsilon\right]}{\operatorname{var}(x)}=\frac{\operatorname{cov}\left[x^{*}+v, \beta\left(x^{*}+v\right)-\beta v+\varepsilon\right]}{\operatorname{var}(x)}=\beta\left(1-\frac{\sigma_{v}^{2}}{\sigma_{x}^{2}}\right)
$$

if $\operatorname{cov}(\varepsilon, v)=\operatorname{cov}\left(\mathrm{x}^{*}, \varepsilon\right)=\operatorname{cov}\left(\mathrm{x}^{*}, \mathrm{v}\right)=0$. If $\sigma_{v}^{2}>0$, i.e. if there is noise in the measurement of the exogenous variable $\mathrm{x}$, it follows that

$$
|\beta|>\left[|\beta|\left(1-\frac{\sigma_{v}^{2}}{\sigma_{x}^{2}}\right)\right]>0
$$

because $\sigma_{x}^{2}>\sigma_{v}^{2}$. Hence, $\beta$ will be biased towards zero. Estimated effects of mismeasured variables are always smaller in absolute value than they are in reality.

Note that there are also theoretical problems concerning the above mentioned measures of market power. Even if we knew all participants in a market and their relative market shares, we would neglect the fact that most goods have more or less close substitutes. Moreover, even if we knew all market participants including those of substitutes, we would disregard competitive pressure resulting from the threat of market entry of new suppliers. In this case public statistics report a too low size of an individual market and hence a too small degree of competition. CORTS (1998) argues that a price mark-up measure is only then appropriate if an industry is characterized by a conjectural variations game. This cannot be assumed for all industries. If an industry is characterized, for example, by efficient supergame collusion the conduct parameter method will yield severely downward-biased estimates of the degree of market power in that industry. Since this downward bias will not be equal for all industries, measurement error is likely to be even higher. Formally, if competition has a positive influence on firm performance and if competition is measured with some error, the estimated coefficient will be biased towards zero. 
Many studies on corporate governance use Tobin's q as the main measure for firm performance (e.g. MORCK et al. 1988, CHO 1998). Implicitly, these studies assume that capital markets know the correct value of a firm and that it is reflected by current market value of shares. Although it is sometimes doubted that this assumption is correct, it simply might be the best measure available.

Empirical studies on Germany usually use other measures (Table 2). The main reason lies in German accounting rules: in annual accounts assets are not reported at their market value. Assets are reported at historical costs, i.e. the value they had at the time of their purchase.

\section{Table 2: Comparison of Performance Measures}

\begin{tabular}{|c|c|}
\hline STUDY & PERFORMANCE MEASURE \\
\hline \multicolumn{2}{|l|}{ Germany: } \\
\hline CABLE (1985) & Year's Result \\
\hline NIBLER (1995) & Result before Taxes \\
\hline CHIRINKO and ELSTON (1996) & Return on Assets \\
\hline GORTON and SCHMID (1996) & Return on Assets, Return on Equity \\
\hline \multicolumn{2}{|l|}{ US and UK: } \\
\hline $\begin{array}{l}\text { DEMSETZ and LEHN (1985), HOLDERNESS and } \\
\text { SHEEHAN (1988) }\end{array}$ & Year's Result \\
\hline $\begin{array}{l}\text { MORCK et al. (1988), MCCONNELL and SERVAES } \\
\text { 1990, CHO (1998) }\end{array}$ & TOBIN's q \\
\hline $\begin{array}{l}\text { NICKELL et al. (1997), NICKELL and NICOLITSAS } \\
\text { (1999) }\end{array}$ & Productivity Growth \\
\hline
\end{tabular}

If these different performance measures indeed proxied for the same (not directly observable) firm performance, they would be highly correlated. Unfortunately they are not. GEROSKI (1998) shows for British firms that the correlation between different performance measures and preconditions for profitability ${ }^{14}$ is rather weak. In addition, even the correlation between performance measures like accounting profits, market value or growth rate of market value is pretty low. This is mainly due to differences in distributions of variables. GEROSKI shows that accounting profits divided by sales are almost normally distributed. But for example the number of patents produced, a precondition for profitability, is highly skewed. Furthermore, while accounting profits mostly have a high variation between firms, growth rates of sales or market

\footnotetext{
${ }^{14}$ These preconditions are, for example, approximated by the number of major innovations or patents produced.
} 
value vary rather within the individual firm (GEROSKI 1998: 6). Thus different measures of performance might be correlated only in a highly non-linear way.

Assume that "firm performance" were a latent variable and its different empirical measures were drawn from the same population. Then we should not expect estimation bias because measurement error in the endogenous variable does not bias coefficients. However, if we cannot prove the robustness of our estimates using different measures of performance, probably there is no congruence between these measures. Hence, all results depend on the measure selected. But this means that assumptions in the process of selecting the relevant performance measure become crucial to our final interpretation of results.

\section{Lessons}

There are several lessons for future research from these examples. Selection of the endogenous variable can be an important determinant of the estimation results we obtain. If different performance measures come from different distributions, estimated coefficients depend on the model we have chosen. On the other hand, if estimates for corporate governance variables are robust to different performance measures, we can be more confident in our results. Such checks of the robustness of coefficients can reduce the dependence on particular assumptions.

The problem is more serious if exogenous variables are measured with error. Cross-checking the explanatory variables in use helps to detect irregularities but requires multiple measures, e.g. on ownership. In case of Germany, ownership data are available from several sources. One source is Hoppenstedt (Company Structure Database), another Commerzbank (Who Owns Whom?). The latter also contains information on the board structure.

As mentioned in section 3, in Germany data on market structure are available from the Antitrust Commission (Monopolkommission) which obtains the data from the Federal Statistical Office (Statistisches Bundesamt). These statistics report the number of suppliers and other measures of concentration on four-digit industry levels. ${ }^{15}$ The task of the researcher is to connect these concentration data with the sales data for each firm in the sample. Here, a major obstacle is German accounting law: since German enterprises are not required to disclose data on sales for their individual markets but only one aggregate figure, the assignment of the con-

\footnotetext{
${ }^{15}$ Note that these statistics include foreign competitors only then when they are registered at a German court. Therefore these competition data are likely to be measured with a bias depending on the industry.
} 
centration data to each firm becomes quite unreliable. In consequence, the resulting competition figure is very likely to be measured with some error.

One way to circumvent this problem is to ask managers directly how intensive competition is because every manager knows his competitors better than any public statistical office. NiCKELL et al. (1997) therefore conducted a survey among managers and tried to assess the true number of competitors for a particular firm.

\section{Conclusions}

This paper serves as a framework or checklist for future empirical corporate governance studies. It fulfills two purposes. First, going through this checklist should clarify where unavoidable problems are and how they can affect estimation and interpretation. Even better, it can prevent biases in the first place. Second, it should raise the awareness for careful data collection, in particular the need for panel data.

Endogeneity of the right-hand side variables is likely to be the most common problem. It generally occurs in two forms: structural reverse causality and unobserved firm heterogeneity. In both cases, panel data are a necessary condition to solve the endogeneity problem. With panel data on hand, fixed-effects models or models in first differences can be estimated to take into account the unobserved part of firm heterogeneity. But this approach fails if unobserved heterogeneity is not constant over time. What must be done is to reduce the unobserved part of the model by including other firm-specific variables. One econometric trick is to use deep lags of right-hand side firm-specific variables. But these might be weak instruments; thus the crucial task to resolve structural reverse causality is the search for uncontroversial instruments.

The problem of missing variables must be avoided by including all theoretically relevant governance mechanisms in the empirical model. Hence, specific data are required for the ownership structure, the debt structure, the board structure, measures of competition and possibly past takeover activity. Since economic theory suggests that some of these variables might have a non-linear influence on firm performance higher order polynomial terms are required.

Sample selectivity is the third source of potential estimation bias. To avoid sampling bias the researcher must take into account major firm decisions like the decision to go public or to exit a product market. This is accomplished by extending the samples to non-listed firms, poten- 
tially of various sizes, and by not dropping observations of firms that exited the market. In a second step, information about market exit must enter the regression model.

Last but not least, measurement error in variables can bias estimation results. Measurement error in exogenous variables clearly biases estimated coefficients. Unfortunately this is likely to be the case for particular variables often used in corporate governance analysis, e.g. measures of competition and ownership structures. There is no simple solution to this problem. One way to check the robustness of estimation results is, however, to use a range of measures if economic theory does not provide us with a clear requirement which measure to use. The same applies to measurement of endogenous variables although measurement error in these variables does not bias estimated coefficients. Previous empirical studies seem to follow this route in so far as many different measures of performance are used. What they often fail to do, however, is to state clearly the assumptions on which their measures were selected. This is not a formalism: many empirical contradictions could be dissolved if models were compared on an equal basis.

A final remark: what appears to be technical problems of econometric analyses, are in fact deep problems of any empirical analysis, independent of the technical tool. The discussed problems do not only occur in regression analyses. The same care should be taken in the interpretation of simple correlations and cross-tables of variables whenever causal interpretations are attempted. 


\section{References}

Agrawal, A. and C.R. Knoeber (1996), Firm Performance and Mechanisms to Control, Journal of Financial and Quantitative Analysis 31 (September), 377-397.

Allen, C., M. Gasiorek and A. Smith (1998), European Single Market, Economic Policy (October), 439-486.

Baily, M.N. and H. Gersbach (1995), Efficiency in Manufacturing and the Need for Global Competition, Brookings Papers on Economic Activity (Microeconomics), 307-347.

Becht, M. and E. Böhmer (1999), Transparency of Ownership and Control in Germany, Working Paper, Universite Libre de Bruxelles.

Berle, A.A. and G.C. Means (1932), The Modern Corporation and Private Property, New York: Macmillan.

Black, B. (1998), Shareholder Activism and Corporate Governance in the United States, in: P. Newman (ed.), The New Palgrave Dictionary of Economics and Law, London: Macmillan.

Börsch-Supan, A. (1999), Capital Productivity and the Nature of Competition. Brookings Papers on Economic Activity, Microeconomics.

Brickley, J.A., R.C. Lease and C.W. Smith, Jr. (1988), Ownership Structure and Voting on Anti-Takeover Amendments, Journal of Financial Economics 20, 267-291.

Cable, J. (1985), Capital Market Information and Industrial Performance: The Role of West German Banks, The Economic Journal 95, 118-132.

Chirinko, R.S. and J.A. Elston (1996), Banking Relationships in Germany: Empirical Results and Policy Implications, Bank Relationships, 239-255.

Cho, M. (1998), Ownership Structure, Investment, and the Corporate Value: An Empirical Analysis, Journal of Financial Economics 47, 103-121.

Cole, R.A. and H. Mehran (1998), The Effect of Changes in Ownership Structure on Performance: Evidence form the Thrift Industry, Journal of Financial Economics 50, 291-317.

Conyon, M.J. and J. Schwalbach (1997a), European Differences in Executive Pay and Corporate Governance, Working Paper, University of Warwick/Humboldt University Berlin.

Conyon, M.J. and J. Schwalbach (1997b), Pay for Performance and Board Effectiveness in Britain and Germany, Working Paper, University of Warwick/Humboldt University Berlin.

Corts, K.S. (1998), Conduct Parameters and the Measurement of Market Power, Journal of Econometrics 88, 227-250.

Cubbin, J. and D. Leech (1983), The Effect of Shareholder Dispersion on the Degree of Control in British Companies: Theory and Measurement, The Economic Journal 93, 351-369.

Del Guercio, D. and J. Hawkins (1999), The Motivation and Impact of Pension Fund Activism, Journal of Financial Economics 52, 293-340.

Demsetz, H. and K. Lehn (1985), The Structure of Corporate Ownership: Causes and Consequences, Journal of Political Economy 93 (6), 1155-1177. 
Denis, D.J. and A. Sarin (1999), Ownership and Board Structures in Publicly Traded Corporations, Journal of Financial Economics 52 (2), 187-224.

Fama, E.F. and M.C. Jensen (1983), Separation of Ownership and Control, Journal of Law and Economics 26, 301-325.

Franks, J. and C. Mayer (1995), Ownership and Control, in: H. Siebert (ed.), Trends in Business Organization, Tübingen: Mohr, 171-200.

Geroski, P.A. (1998), An Applied Econometricans' View of Large Company Performance, Working Paper, Centre for Economic Policy Research, London.

Gordon, A.L. and J. Pound (1993), Information, Ownership Structure, and Shareholder Voting: Evidence from Shareholder-Sponsored Corporate Governance Proposals, Journal of Finance 48 (2), 697-718.

Gorton, G. and F.A. Schmid (1996), Universal Banking and the Performance of German Firms, Working Paper, University of Pennsylvania.

Greene, W.H. (1997), Econometric Analysis, $3^{\text {rd }}$ ed., Upper Saddle River/NJ: Prentice Hall.

Grossman, S.J. and O.D. Hart (1980), Takeover Bids, the Free-Rider Problem, and the Theory of the Corporation, Bell Journal of Economics 11, 42-64.

Hart, O.D. (1983), The Market Mechanism as an Incentive Scheme, Bell Journal of Economics 14 (3), 366-382.

Heckman, J. (1976), The Common Structure of Statistical Models of Truncation, Sample Selection, and Limited Dependent Variables and a Simple Estimator for Such Models, The Annals of Economic and Social Measurement 5, 475-492.

Hellwig, M. (1997), Unternehmensfinanzierung, Unternehmenskontrolle und Ressourcenallokation: Was leistet das Finanzsystem?, in: B. Gahlen, H. Hesse und H.J. Ramser (eds.), Finanzmärkte, Tübingen: Mohr, 211-243.

Hermalin, B.E. (1992), The Effects of Competition on Executive Behavior, RAND Journal of Economics 23, 350-365.

Himmelberg, C.P., G.R. Hubbard and D. Palia (1999), Understanding the Determinants of Managerial Ownership and the Link Between Ownership and Performance, Journal of Financial Economics 53 (3), 353-384.

Holderness, C.G. and D.P. Sheenan (1988), The Role of Majority Shareholders in Publicly Held Corporations: An Exploratory Analysis, Journal of Financial Economics 20, 317-346.

Hopt, K.J., The German Two-Tier Board (Aufsichtsrat) A German View on Corporate Governance, in: K.J. Hopt and E. Wymeersch (eds.), Comparative Corporate Governance: Essays and Materials, Berlin: Walter de Gruyter, 3-20.

Januszewski, S.I., F.J. Köke and J.K. Winter (1999), Product Market Competition and Corporate Governance: An Empirical Investigation for Germany, ZEW Discussion Paper No. 99-63, Centre for European Economic Research, Mannheim.

Jensen, M. and K.J. Murphy (1990), Performance Pay and Top-Management Incentives, Journal of Political Economy 98 (2), 225-264.

Jensen, M. and R. Ruback (1983), The Market for Corporate Control, Journal of Financial Economics 11, 5-50.

Jensen, M.C. (1986), Agency Costs of Free Cash Flow, Corporate Finance, and Takeovers, American Economic Review 76, 323-329. 
Jensen, M.C. (1988), Takeovers: Their Causes and Consequences, Journal of Economic Perspectives 2, 21-48.

Jensen, M.C. (1993), The Modern Industrial Revolution, Exit, and the Failure of Internal Control Systems, Journal of Finance 48 (3), 831-880.

Jensen, M.C. and W.H. Meckling (1976), Theory of the Firm: Managerial Behavior, Agency Costs, and Ownership Structure, Journal of Financial Economics 3, 305-360.

Kang, D.L (1998), The Internal Control of Organizations: How Large-Block Ownership by Insiders Leads to Increase Firm Performance, Working Paper, Harvard Business School.

Kaplan, S.N. (1994a), Top Executives, Turnover, and Firm Performance in Germany, Journal of Law, Economics and Organization 10 (1), 142-159.

Kaplan, S.N. (1994b), Top Executive Rewards and Firm Performance: A Comparison of Japan and the United States, Journal of Political Economy 102 (3), 510-546.

Karpoff, J.M. (1998), The Impact of Shareholder Activism on Target Companies: A Survey of Empirical Findings, Working Paper, University of Washington.

Köke, F.J. (1999), New Evidence on Ownership Structures in Germany, ZEW Discussion Paper No. 99-60, Centre for European Economic Research, Mannheim.

Kole, S. and K. Lehn (1997), Deregulation, the Evolution of Corporate Governance Structure, and Survival, American Economic Review 87 (2), 421-425.

Kole, S. and K. Lehn (1999), Deregulation and the Adaptation of Governance Structure: The Case of the US Airline Industry, Journal of Financial Economics 52, 79-117.

Leech, D. and J. Leahy (1991), Ownership Structure, Control Type Classifications and the Performance of Large British Companies, Economic Journal 101, 1418-1437.

Leland, H. and D. Pyle (1977), Information Asymmetries, Financial Structure and Financial Intermediation, Journal of Finance 42 (5), 371-387.

Maddala, G.S. (1983), Limited-Dependent Variables and Qualitative Variables in Econometrics, Cambridge: Cambridge University Press.

McConnell, J.J. and H. Servaes (1990), Additional Evidence on Equity Ownership and Corporate Value, Journal of Financial Economics 27, 595-612.

McWilliams, V.B. and N. Sen (1997), Board Monitoring and Anti-Takeover Amendments, Journal of Financial and Quantitative Analysis 32 (4), 491-505.

Morck, R., A. Shleifer and R.W. Vishny (1988), Management Ownership and Market Valuation, Journal of Financial Economics 20, 292-315.

Murali, R. and J.B. Welch (1989), Agents, Owners, Control and Performance, Journal of Business Finance and Accounting 16 (3), 385-398.

Nibler, M. (1995), Bank Control and Corporate Performance in Germany: The Evidence, Working Paper, University of Cambridge.

Nickell, S. and D. Nicolitsas (1999), How Does Financial Pressure Affect Firms?, European Economic Review 43, 1435-1456.

Nickell, S., D. Nicolitsas and N. Dryden (1997), What Makes Firms Perform Well?, European Economic Review 41, 783-796.

OECD (1998), Special Features Shareholder Value and the Market in Corporate Control in OECD Countries, Financial Market Trends 69, 15-37. 
Pagano, M. and A. Röell (1996), The Choice of Stock Ownership Structure: Agency Costs, Monitoring, and the Decision To Go Public, in: M. Pagano and A. Röell (eds.), The Decision To Go Public and the Stock Market, Rom: Tipor, 41-75.

Porter, Michael E., 1992, Capital Disadvantage: America's Failing Capital Investment System, Harvard Business Review, 70 (5), 65-82.

Pound, J. (1988), Proxy Contests and the Efficiency of Shareholder Oversight, Journal of Financial Economics 20, 237-265.

Scharfstein, D. (1988), The Disciplinary Role of Takeovers, Review of Economic Studies 55, 185-199.

Seger, F. (1997), Banken, Erfolg und Finanzierung, Wiesbaden: Gabler.

Shleifer, A. and R.W. Vishny (1986), Large Shareholders and Corporate Control, Journal of Political Economy 94 (3), 461-488.

Shleifer, A. and R.W. Vishny (1997), A Survey of Corporate Governance, Journal of Finance $52(2), 737-783$.

Short, H. (1994), Ownership, Control, Financial Structure and the Performance of Firms, Journal of Economic Surveys 8 (3), 203-247.

Smith, M.P. (1996), Shareholder Activism by Institutional Investors: Evidence from CalPERS, Journal of Finance 51 (1), 227-252.

Steiner, M. (1998), Konstitutive Entscheidungen, in: M. Bitz et al. (eds.), Vahlens Kompendium der Betriebswirtschaftslehre, $4^{\text {th }}$ ed., München: Vahlen, Vol. 1, 57-106.

Verbeek, M. and T. Nijman (1996), Incomplete Panels and Selection Bias, in: L. Màtyàs and P. Sevestre (eds.), The Econometrics of Panel Data, $2^{\text {nd }}$ ed., Dordrecht: Kluwer, 449490.

Wenger, E. and C. Kaserer (1997), German Banks and Corporate Governance - A Critical View, Working Paper, University of Würzburg.

Yermack, D. (1996), Higher Market Valuation of a Company with a Small Board of Directors, Journal of Financial Economics 40, 185-211.

Zingales, L. (1998), Survival of the Fittest or the Fattest? Exit and Financing in the Trucking Industry, Journal of Finance 53 (3), 905-938.

Zwiebel, J. (1996), Dynamic Capital Structure under Managerial Entrenchment, American Economic Review 86 (5), 1197-1215. 